\title{
Pengaruh Perbedaan Aras Starter dan Lama Pemeraman terhadap Kecernaan Bahan Kering dan Kecernaan Bahan Organik secara In Vitro Fermentasi Kelobot Jagung (Zea mays) Teramoniasi
}

\author{
Effects of Different Starter Levels and Ripening Duration on In Vitro Dry Matter Digestibility \\ and Organic Matter Digestibility of Ammoniated Corn Husk
}

\author{
R. Septianto, B. I. M. Tampoebolon dan B.W.H.E. Prasetiyono \\ Fakultas Peternakan dan Pertanian, Universitas Diponegoro \\ Kampus drh. R. Soedjono Koesoemowardjojo Tembalang, Semarang 50275 \\ Corresponding Author: roby.septianto@yahoo.co.id
}

\begin{abstract}
This research aimed to examine the effect of combination treatments of the different in starter level and length of ripening of fermentation on digestion of dry matter and organic matter. This work used a completely randomized factorial design, with the treatments of starter levels Aspergillus niger (0; 2,5 and 5\%) and the ripening time of $(0 ; 1$ and 2 weeks). Parameters observed were dry material and organic matter digestibility. The data obtained was analyzed using Analysis of Variance / ANOVA, if there was a treatment effect, then continued with Duncan's multiple range test. The results showed that the combination of starter level treatments and ripening time had a significant effect $(\mathrm{p}<0.05)$ on the digestibility of dry matter and organic matter of fermented corn husk. Based on the results of this research it can be concluded that the interaction treatment of giving starter levels as much 5\% with ripening time of 2 weeks can improved the quality of the best ammonia process corn husk in terms of incrasing dry matter and organic matter digestibility.
\end{abstract}

Key words: Corn husk, Aspergillus niger, dry matter digestibility, organic matter digestibility

\begin{abstract}
ABSTRAK
Penelitian bertujuan untuk mengkaji pengaruh kombinasi perlakuan perbedaan aras starter dan lama pemeraman fermentasi terhadap kecernaan bahan kering dan kecernaan bahan organik klobot jagung teramoniasi. Penelitian ini menggunakan rancangan acak lengkap pola faktorial, dengan perlakuan aras starter Aspergillus niger ( $0 ; 2,5$; dan $5 \%$ ) dan lama pemeraman $(0,1$, dan 2 minggu). Parameter yang diamati adalah kecernaan bahan kering dan kecernaan bahan organik. Data yang diperoleh dianalisis menggunakan Analysis of Variance / ANOVA, apabila terdapat pengaruh perlakuan, maka dilanjutkan dengan uji wilayah ganda Duncan. Hasil penelitian menunjukkan bahwa kombinasi perlakuan aras starter dan lama pemeraman berpengaruh nyata $(p<0,05)$ terhadap kecernaan bahan kering dan kecernaan bahan organik kelobot jagung teramoniasi. Berdasarkan hasil penelitian dapat disimpulkan bahwa interaksi perlakuan pemberian aras starter sebanyak 5\% dengan lama waktu pemeraman 2 minggu dapat meningkatkan kualitas kelobot jagung teramoniasi terbaik yang ditinjau dari peningkatan kecernaan bahan kering dan kecernaan bahan organik.
\end{abstract}

Kata kunci : Kelobot jagung, Aspergillus niger, $\mathrm{KcBK}, \mathrm{KcBO}$

\section{PENDAHULUAN}

Pakan adalah faktor terbesar yang mempengaruhi sebuah usaha peternakan. Semakin berkembangnya dunia peternakan, maka efektivitas penggunaan pakan juga harus ditingkatkan. Kelebihan penggunaan hasil samping pertanian berupa kelobot jagung sebagai pakan ternak tidak bersaing dengan kebutuhan manusia dan ketersediannya yang melimpah di berbagai musim. Kelobot jagung merupakan kulit yang membungkus dari buah jagung. Kelobot jagung biasanya langsung dibuang begitu saja dan tidak dimanfaatkan. Kelobot jagung memiliki hasil panen yang cukup tinggi. Retnani et al. (2009) menyatakan bahwa produksi tanaman jagung di Indonesia mencapai 17.659.067 ton dengan luasan panen 4.194.143 ha, maka perkiraan produksi tanaman jagung per ha adalah 4,2 ton dan kelobot jagung memiliki proporsi $10 \%$ dari total bagian dari buah jagung. 
Kelobot jagung memiliki tingkat produksi terkecil diantara hasil samping jagung lainnya seperti tongkol jagung, jerami jagung dan batang jagung (Wayan et al, 2015). Proporsi hasil samping tanaman jagung dalam persen bahan kering terdiri dari $50 \%$ batang, 20\% daun, 20\% tongkol dan 10\% kelobot (McCutcheon dan Samples 2002). Kelobot jagung merupakan hasil samping pertanian yang dapat dimanfaaatkan untuk pakan ternak baik diberikan secara langsung maupun diolah terlebih dahulu.

Bahan pakan berkualitas dapat dilihat dari kualitas nutrisinya, selain itu dapat juga dilihat dari kecernaan bahan kering dan bahan organik. Kecernaan sebagai bagian yang tidak diekskresikan dalam feses dan lainnya diasumsikan untuk diserap oleh ternak yang dinyatakan dalam persen bahan kering. Kandungan nutrisi yang tinggi pada pakan dapat menyebabkan pemanfaatan yang cukup tinggi pada rumen ternak ruminansia. Tingginya kecernaan bahan kering pada pakan menunjukkan bahwa pakan tersebut dapat dimanfaatkan dengan baik untuk pertumbuhan ternak. Teknologi pengolahan pakan saat ini telah dikembangkan, dan salah satu hasil dari pengembangannya adalah pakan fermentasi. Pakan fermentasi merupakan pakan ternak yang diawetkan atau diolah dengan cara penambahan menggunakan mikrobia tertentu, untuk menghasilkan enzim yang dapat mencerna serat dan menghambat mikrobia perusak dengan menghasilkan asam.

Fermentasi merupakan cara pengolahan pakan ternak dengan bantuan mikroba sehingga senyawa kompleks yang ada pada tanaman (seperti bagian serat kasarnya) menjadi senyawa yang lebih sederhana dan mudah dicerna. Proses fermentasi dipengaruhi oleh beberapa faktor diantaranya: jenis dan jumlah starter, jenis substrat, $\mathrm{pH}$, dan suhu serta lama proses pemeraman. Tujuan penelitian ini untuk mengkaji kombinasi perlakuan perbedaan aras starter dan waktu peram dalam proses fermentasi kelobot jagung teramoniasi dengan Aspergillus niger terhadap kecernaan bahan kering dan kecernaan bahan organik

\section{MATERI DAN METODE}

Penelitian dilaksanakan selama 6 bulan di Laboratorium Teknologi Pengolahan Pakan dan Laboratorium Ilmu Nutrisi Pakan, Fakultas Peternakan dan Pertanian, Universitas Diponegoro, Semarang. Materi yang digunakan dalam penilitian yaitu kelobot jagung, alkohol 90\%, tetes tebu, aquades, $\mathrm{H}_{2} \mathrm{SO}_{4} \quad 0,3 \mathrm{~N}, \mathrm{NaOH} 1,5 \mathrm{~N}, \mathrm{HCl}$ $0,1 \mathrm{~N}$.

Alat yang digunakan terdiri dari gunting, timbangan digital, nampan, botol kaca, oven, bunsen, spluit, mortar, plastic klip, kertas label, cawan petri, eksikator, penjepit cawan, tanur, erlenmeyer $600 \mathrm{ml}$, kertas saring, spatula, kapas, buret, erlenmeyer $100 \mathrm{ml}$, gelas beaker, dan alat tulis. Metode yang digunakan dalam penelitian ini meliputi rancangan penelitian, prosedur penelitian, dan analisis data.

\section{Rancangan Penelitian}

Penelitian ini menggunakan

Rancangan Acak Lengkap (RAL) pola factorial (3x3) dengan 3 ulangan. Perlakuan yang dilakukan adalah sebagai berikut :

$\mathrm{T}_{0} \mathrm{M}_{0}=$ kelobot jagung amoniasi $+A$. niger $0 \%$ + pemeraman 0 minggu

$\mathrm{T}_{0} \mathrm{M}_{1}=$ kelobot jagung amoniasi + A. niger $0 \%+$ pemeraman 1 minggu

$\mathrm{T}_{0} \mathrm{M}_{2}=$ kelobot jagung amoniasi + A. niger $0 \%+$ pemeraman 2 minggu

$\mathrm{T}_{1} \mathrm{M}_{0}=$ kelobot jagung amoniasi $+A$. niger $2,5 \%+$ pemeraman 0 minggu

$\mathrm{T}_{1} \mathrm{M}_{1}=$ kelobot jagung amoniasi $+A$. niger $2,5 \%+$ pemeraman 1 minggu

$\mathrm{T}_{1} \mathrm{M}_{2}=$ kelobot jagung amoniasi + A. niger $2,5 \%+$ pemeraman 2 minggu

$\mathrm{T}_{2} \mathrm{M}_{0}=$ kelobot jagung amoniasi + A. niger $5 \%+$ pemeraman 0 minggu

$\mathrm{T}_{2} \mathrm{M}_{1}=$ kelobot jagung amoniasi + A. niger $5 \%+$ pemeraman 1 minggu

$\mathrm{T}_{2} \mathrm{M}_{2}=$ kelobot jagung amoniasi + A. niger $5 \%+$ pemeraman 2 minggu 


\section{Prosedur Penelitian}

Prosedur penelitian ini meliputi tahap persiapan, tahap perlakuan dan tahap analisis. Tahap persiapan pertama melakukan pencacahan kelobot jagung dengan panjang 2-3 cm. Tahapan pembuatan Aspergillus niger, tahapan pembuatan amoniasi kelobot jagung, dengan suhu $60{ }^{0} \mathrm{C}$ selama 4 hari, pencucian kelobot jagung teramoniasi, pengangin - anginan kelobot teramoniasi, pemanenan Aspergillus niger.

Pada tahapan perlakuan kelobot jagung teramoniasi dicampur dengan tetes tebu dan air kemudian dicampurkan dengan Aspergillus niger dengan pencampuran ( 0 , 2,5 dan 5\%). Pengamatan dilakukan pada minggu ke-0, minggu ke-1 dan minggu ke-2 pada penyimpanan suhu ruang.

Pada tahap analisis prinsip dari analisis kecernaan bahan kering menggunakan metode Tilley dan Terry (1963) yaitu dengan memasukan sampel pada oven dengan suhu 105-110 ${ }^{\circ} \mathrm{C}$. Prosedur dari Analisis Kecernaan Bahan Kering yang pertama adalah menyaring sisah pencernaan dengan kertas saring (bebas abu dan sudah diketahui bobotnya) dengan bantuan pompa vakum dan dibilas dengan aquades secukupnya. Selanjutnya di anginkan terlebih dahulu, setelah dianginkan kemudian cuci atau bilas cawan perselin (CP) yang sudah diketahui bobotnya lalu dikeringkan kedalam oven dengan suhu 105$110{ }^{\circ} \mathrm{C}$ selama 24 jam, kemudian didinginkan dalam deksikator selama 15 menit dan ditimbang (untuk mengetahui bahan kering). Tahap akhir adalah menghitung Kecernaan Bahan Kering dengan rumus :
$\mathrm{KcBK}=\frac{\mathrm{BK} \text { Sampel }-(\mathrm{BK} \text { Residu }- \text { BK Blanko })}{\% \text { BK Sampel }} \times 100$

Prinsip dari analisis kecernaan bahan organik adalah menghilangkan semua bahan-bahan organik dari sampel dengan cara memijarkan dalam tanur listrik pada suhu $400-600{ }^{\circ} \mathrm{C}$ selama 4-6 jam. Prosedur dari Analisis Kecernaan Bahan Organik yang pertama adalah menyaring sisah pencernaan dengan kertas saring (bebas abu dan sudah diketahui bobotnya) dengan bantuan pompa vakum dan dibilas dengan aquades secukupnya. Selanjutnya di anginkan terlebih dahulu, setelah dianginkan kemudian cuci atau bilas cawan porselin (CP) yang sudah diketahui bobotnya lalu dikeringkan kedalam oven dengan suhu $105-110^{\circ} \mathrm{C}$ selama 24 jam, kemudian didinginkan dalam eksikator selama 15 menit dan ditimbang (untuk mengetahui bahan kering). Selanjutnya sampel dalam cawan petri diabukan atau dimasukkan ke dalam tanur listrik pada suhu 400-600 ${ }^{\circ} \mathrm{C}$ selama 6 jam, kemudian didinginkan hingga suhu stabil lalu ditimbang. Tahap akhir adalah menghitung Kecernaan Bahan Organik dengan rumus :

$$
\mathrm{KcBO}=\frac{\text { BO Sampel }-(\text { BO Residu }- \text { BO Blanko })}{\% \text { BO Sampel }} \times 100
$$

\section{HASIL DAN PEMBAHASAN}

\section{Kecernaan Bahan Kering Kelobot}

Hasil penelitian tentang pengaruh perlakuan aras starter (A. niger) dan lama fermentasi terhadap kecernaan bahan kering kelobot jagung teramoniasi pada masingmasing perlakuan disajikan pada Tabel 1

Tabel 1. Data analisis kecernaan bahan kering kelobot jagung teramoniasi

\begin{tabular}{|c|c|c|c|c|}
\hline \multirow{2}{*}{ Aras Starter $(\%)$} & \multicolumn{3}{|c|}{ Lama Pemeraman (minggu) } & \multirow[t]{2}{*}{ Rataan } \\
\hline & $\mathrm{M}_{0}$ & $\mathrm{M}_{1}$ & $\mathrm{M}_{2}$ & \\
\hline & \multicolumn{4}{|c|}{------------------------------" } \\
\hline $\mathrm{T}_{0}$ & $31,52^{\mathrm{e}}$ & $32,17^{\mathrm{d}}$ & $33,80^{\mathrm{d}}$ & 32,50 \\
\hline $\mathrm{T}_{1}$ & $37.90^{\mathrm{d}}$ & $43,38^{\mathrm{c}}$ & $53,60^{\mathrm{b}}$ & 44,96 \\
\hline $\mathrm{T}_{2}$ & $40,78^{\mathrm{c}}$ & $54,97^{\mathrm{b}}$ & $66,50^{\mathrm{a}}$ & 54,08 \\
\hline Rataan & 36,73 & 43,51 & 51,30 & \\
\hline
\end{tabular}

Ket.: Superskripyang berbeda pada baris dan kolom yang berbeda menunjukkan perbedaan nyata $(\mathrm{P}<0,05)$ 
Perlakuan penambahan Aspergillus niger dan lama peram dapat meningkatkan KcBK. KcBK berkisar antara 31,52 sampai 66,50 dengan rata - rata $43,85 \%$. Rata - rata KcBK fermentasi ini lebih tinggi dari rata rata KcBK kelobot jagung tanpa perlakuan $(31,52 \%)$. Hasil analisis ragam menunjukkan bahwa kombinasi perlakuan penambahan aras starter sampai $5 \%$ dan peningkatan lama waktu pemeraman sampai 2 minggu menunjukkan adanya interaksi yang nyata $(\mathrm{P}<0,05)$ terhadap peningkatan KcBK. Hal ini berarti dari kedua perlakuan yaitu lama peram dan peningkatan aras saling mempengaruhi untuk dapat meningkatkan KcBK.

Peningkatan lama waktu pemeraman dan jumlah aras akan menyebabkan semakin menurunnya serat kasar kelobot jagung teramoniasi, sehingga akan meningkatkan kecernaanya. Perlakuan perbedaan aras starter dan lama waktu pemeraman fermentasi bersamaan saling mempengaruhi untuk meningkatkan kecernaan bahan kering. Semakin banyak jumlah aras starter dan semakin lama waktu pemeraman fermentasi, maka kecernaan bahan kering akan meningkat.Hal ini dapat terjadi karena pada awal pemeraman pertumbuhan mikroba (starter) masih belum optimal dan masih dalam tahap adaptasi, sehingga degradasi serat belum optimal, akibatnya kecernaan juga tidak maksimal. Judoamidjojo et al. (1989) menyatakan bahwa peningkatan lama waktu pemeraman pada fermentasi menyebabkan meningkatnya kesempatan mikroba untuk melakukan pertumbuhan dan proses fermentasi, sehingga semakin lama waktu pemeraman maka kesempatan mikroba selulolitik untuk mendegradasi jerami padi semakin tinggi.
Kecernaan bahan kering tertinggi terjadi pada kombinasi perlakuan $\mathrm{T}_{2} \mathrm{M}_{2}$ $(66.50 \%)$ dengan jumlah aras starter 5\% dan lama pemeraman 2 minggu. Pengujian lanjut menggunakan uji Duncan terhadap kecernaan bahan kering fermentasi kelobot jagung teramoniasi menunjukkan bahwa kombinasi perlakuan $\mathrm{T}_{2} \mathrm{M}_{2} \quad(66.50 \%)$ nyata $(\mathrm{p}<0,05)$ lebih tinggi dibanding $\mathrm{T}_{0} \mathrm{M}_{0}(31,52 \%), \mathrm{T}_{0} \mathrm{M}_{1}$ (32,17\%), $\mathrm{T}_{0} \mathrm{M}_{2}(33,80 \%), \mathrm{T}_{1} \mathrm{M}_{0}(37,90 \%)$, $\mathrm{T}_{1} \mathrm{M}_{1} \quad(43,38 \%), \quad \mathrm{T}_{1} \mathrm{M}_{2} \quad(53,60 \%), \quad \mathrm{T}_{2} \mathrm{M}_{0}$ (40,78\%), dan $\mathrm{T}_{2} \mathrm{M}_{1}(54,97 \%)$. Prastyawan (2012) menyatakan bahwa kecernaan bahan kering pada tongkol jagung amofer meningkat seiring dengan masing - masing perlakuan peningkatan aras starter dan lama waktu pemeraman, semakin tinggi aras starter sampai $2 \%$ dan semakin lama waktu pemeraman sampai 4 minggu nilai $\mathrm{KcBK}$ semakin meningkat. Faktor yang berpengaruh terhadap kecernaan dapat ditinjau dari kandungan serat, jenis pakan dan cara pengolahan.

\section{Kecernaan Bahan Organik Kelobot}

Hasil penelitian pengaruh perlakuan aras starter (A. niger) dan lama pemeraman yang berbeda terhadap kecernaan bahan organik kelobot jagung teramoniasi pada masing-masing perlakuan disajikan pada Tabel 2. Secara umum, perlakuan penambahan Aspergillus niger dan lama peram dapat meningkatkan $\mathrm{KcBO}$. $\mathrm{KcBO}$ berkisar antara 32,46 sampai 67,64\% dengan rata - rata 45,34\%. Rata - rata KcBO fermentasi ini lebih tinggi dari rata -rata $\mathrm{KcBO}$ kelobot jagung tanpa perlakuan $(32,46 \%)$. Besarnya KcBO ini dipengaruhi juga oleh KcBK.

Tabel 2. Data analisis kecernaan bahan organik kelobot jagung teramoniasi

\begin{tabular}{|c|c|c|c|c|}
\hline \multirow{2}{*}{ Aras Starter (\%) } & \multicolumn{3}{|c|}{ Lama Pemeraman (minggu) } & \multirow[t]{2}{*}{ Rataan } \\
\hline & $\mathrm{M}_{0}$ & $\mathrm{M}_{1}$ & $\mathrm{M}_{2}$ & \\
\hline & \multicolumn{3}{|c|}{ - } & \\
\hline $\mathrm{T}_{0}$ & $32,46^{\mathrm{f}}$ & $33,83^{\mathrm{e}}$ & $35,38^{\mathrm{e}}$ & 33,89 \\
\hline $\mathrm{T}_{1}$ & $38,52^{\mathrm{d}}$ & $44,36^{\mathrm{c}}$ & $56,93^{\mathrm{b}}$ & 46,60 \\
\hline $\mathrm{T}_{2}$ & $42,27^{\mathrm{c}}$ & $56,68^{\mathrm{b}}$ & $67,64^{\mathrm{a}}$ & 55,53 \\
\hline Rataan & 37,75 & 44,96 & 53,32 & \\
\hline
\end{tabular}

Ket.: Superskripyang berbeda pada baris dan kolom yang berbeda menunjukkan perbedaan nyata $(\mathrm{p}<0,05)$ 
Hasil analisis ragam menunjukkan bahwa kombinasi perlakuan penambahan aras starter sampai 5\% dan peningkatan lama waktu pemeraman sampai 2 minggu menunjukkan adanya interaksi yang nyata $(\mathrm{p}<0,05)$ terhadap peningkatan $\mathrm{KcBO}$.

$\mathrm{Hal}$ ini berarti kedua faktor perlakuan tersebut (peningkatan aras dan lama pemeraman) saling mempengaruhi untuk meningkatkan KcBO. Perlakuan perbedaan aras starter dan lama waktu pemeraman fermentasi bersamaan saling mempengaruhi untuk meningkatkan kecernaan bahan organik. Semakin banyak jumlah aras starter dan semakin lama waktu pemeraman fermentasi, maka kecernaan bahan organik akan meningkat. Peningkatan lama waktu pemeraman menyebabkan meningkatnya mikrobia starter untuk melakukan pertumbuhan fermentasi, sehingga semakin lama waktu pemeraman, maka kesempatan untuk mendegradasi kelobot jagung semakin tinggi. Peningkatan kecernaan bahan kering juga akan menyebabkan peningkatan kecernaan bahan organik. Hal ini sesuai dengan pendapat Tillman et al. (1998) yang menyatakan bahwa peningkatan kecernaan bahan kering $(\mathrm{KcBK})$ dapat menyebabkan peningkatan kecernaan bahan organik (KcBO) karna bahan kering terdiri dari bahan organik.

Pengujian uji Duncan terhadap kecernaan bahan organik fermentasi kelobot jagung teramoniasi menunjukkan bahwa kombinasi perlakuan $\mathrm{T}_{2} \mathrm{M}_{2}(67.64 \%)$ nyata ( $\mathrm{p}<0,05)$ lebih tinggi dibanding $\mathrm{T}_{0} \mathrm{M}_{0}$ (32,46\%), $\mathrm{T}_{0} \mathrm{M}_{1}(33,83 \%), \mathrm{T}_{0} \mathrm{M}_{2}(35,38 \%)$, $\begin{array}{llll}\mathrm{T}_{1} \mathrm{M}_{0} \quad(38,52 \%), & \mathrm{T}_{1} \mathrm{M}_{1} \quad(44,36 \%), & \mathrm{T}_{1} \mathrm{M}_{2}\end{array}$ $(56,93 \%), \quad \mathrm{T}_{2} \mathrm{M}_{0} \quad(42,27 \%), \quad$ dan $\quad \mathrm{T}_{2} \mathrm{M}_{1}$ $(56,68 \%)$. Kecernaan bahan organik tertinggi terjadi pada kombinasi perlakuan aras starter $\mathrm{T}_{2}(5 \%)$ dan lama peram $\mathrm{M}_{2}(2$ minggu) dengan persentase 67.64. Semakin tinggi persentase bahan organik, maka semakin baik kandungan nutrisi yang ada. Syahril et al. (2012) menyatakan bahwa semakin tinggi degradasi bahan organik pakan maka semakin tinggi nutrien yang dapat digunakan untuk memenuhi kebutuhan nutrisi ternak. Kecernaan bahan organik meningkat seiring dengan perlakuan peningkatan aras starter dan lama waktu pemeraman. Semakin tinggi aras starter sampai 5\% dan semakin lama waktu pemeraman sampai 14 hari, nilai $\mathrm{KcBO}$ semakin meningkat.

\section{KESIMPULAN}

Berdasarkan hasil penelitian dapat disimpulkan bahwa kombinasi perlakuan aras starter dan lama pemeraman dapat meningkatkan kecernaan bahan kering, dan kecernaan bahan organic fermentasi kelobot jagung teramoniasi. Hasil kombinasi perlakuan terbaik dicapai pada perlakuan aras $5 \%$ dan lama pemeraman 2 minggu $\mathrm{T}_{2} \mathrm{M}_{2}$ $66,50 \%(\mathrm{KcBK})$ dan 67,64 (KcBO).

\section{DAFTAR PUSTAKA}

Aleonor, M. H. 2008. Peningkatan Kualitas Nutritif Putak Melalui Fermentasi Campuran Trichoderma reesei dan Aspergillus niger sebagai Pakan Ruminansia. Institut Pertanian Bogor. Bogor. (Skripsi)

Amin, M., S. D. Hasan, O. Yanuarianto, M. Iqbal dan I. W. Karda. 2016. Peningkatan Kualitas Jerami Padi Menggunakan Teknologi Amoniasi Fermentasi. J. Ilmu dan Teknologi Peternakan Indonesia. 2(1) : 96-103.

Andayani, J. 2010. Evaluasi kecernaan in vitro bahan kering, bahan organik danprotein kasar penggunaan kulitbuah jagung amoniasi dalam ransum ternak sapi. J. Ilmiah IlmuIlmu Peternakan. 8(5): 252-259.

Anggorodi, R. 1990. Ilmu Makanan Ternak Umum. PT. Gramedia Pustaka Utama, Jakarta.

Arief, R. W., I. Irawati dan Yusmari. 2008. Penurunan Kadar Asam Fitat Tepung Gandum selama Proses Fermentasi. Fakultas Pertanian Universitas Lampung, Lampung. 
Crowder, L. V., dan H. R. Cheda. 1982. Tropical Grassland Husbandry, Logmans, New York.

Furqaanida, N. 2004. Pemanfaatan Kelobot Jagung sebagai Substitusi Sumber Serat Ditinjau dari Kualitas Fisik dan Palatabilitas Wafer Ransum Komplit untuk Domba. Fakultas Peternakan. Institut Pertanian Bogor. Bogor. (Skripsi)

Hastuti, D. dan N.B.I.M. Shofia. 2011. Pengaruh perlakuan teknologi amofer (amoniasi fermentasi) pada hasil samping tongkol jagung sebagai alternative pakan berkualitas ternak ruminansia. Mediagro 7(1) : 55-65.

Indah, E. W. 2010. Uji Kualitas Fisik dan Palatabilitas Biskuit Hasil Samping Tanaman Jagung sebagai Substitusi Sumber Serat untuk Domba. Institut Pertanian Bogor, Bogor. (Skripsi).

Iskandar, B. M. T. 2009. Kajian Perbedaan Aras dan Lama Pemeraman Fermentasi Ampas Sagu Dengan Aspergillus niger Terhadap Kandungan Protein Kasar dan Serat Kasar. Seminar Nasional Kebangkitan Peternakan, Semarang.

Judoamidjojo, M., Said, L. Hartoti, 1989. Biokonversi. Pusat Antar Universitas. Bioteknologi. Intitut Pertanian Bogor, Bogor.

Krisnan, R. 2005. Pengaruh pemberian ampas teh (Camellia sinensis) fermentasi dengan Aspergillus niger pada ayam broiler. J. Ilmu Ternak Veteriner 10(1) : 1-5.

Liu, J., L. Boqun, Z. Liuyang, W. Ping, J. Meiting, and W. Wentao. 2017. Solid-State Fermentation of Ammoniated Corn Straw to Animal
Feed by Pleurotus ostreatus Pl-5. BioResources 12(1) : 1723-1736.

Lopez, S. 2005. In vitro and In situ techniques for estimating digestibility. Dalam J. Dijkstra, M. Forbes, J. France (Eds). Quantitative Aspect of Ruminant Digestion and Metabolism. CABI Publishing, London.

McCutcheon, J and D. Samples. 2002. Grazing Corn Residues. US. Extension Fact Sheet Ohio State University Extension, ANR 10-02.

Ndun, M. L. 2001. Degradabilitas Bahan Kering, Bahan Organik, Protein Kasar Rumput Kumpai Tembaga Yang Diukur Dengan Metode In vitro. Skripsi - Fapet Undana, Kupang.

Nisa, M., M. Sarwar, and M. A. Khan. 2004. Nutritive value of urea treated wheat straw ensiled with or without corn steep liquor for lactating NiliRavi Buffaloes. Asian-Aust. J. Anim. Science. 17(6): 825-829.

Pelczar, M.J., dan E.C.S. Chan. 1986. Dasar - dasar Mikrobiologi. Penerjemah : R.S. Hadioetomo, et. al. UI Press, Jakarta.

Prastyawan, R. M., B. I. M. Tampoebolon dan Surono. 2012. Peningkatan Kualitas Tongkol Jagung Melalui Teknologi Amoniasi Fermentasi (Amofer) terhadap Kecernaan Bahan Kering dan Bahan Organik serta Protein Total secara In Vitro. Animal Agriculture Journal. 1(1), 611-621.

Steel, R. G. D. dan J. H. Torrie. 1991. Prinsip dan Prosedur Statistika Suatu Pendekatan Biometrik (Terjemahan : Sumantri, B.). Gramedia, Jakarta. 
Sumarsih, S dan B. I. M. Tampoebolon. 2003. Pengaruh Aras Urea dan Lama Pemeraman yang Berbeda terhadap Sifat Fisik Eceng Gondok Teramoniasi. Jurnal Pengembangan Peternakan Tropis. 4: 298-301.

Sumarsih, S., C. I. Sutrisno, dan E. Pangestu. 2007. Kualitas nutrisi dan kecernaan daun eceng gondok amoniasi yang difermentasi dengan Trichordema viride pada berbagai lama pemeraman secara in vitro. Journal Indonesian Tropic Animal Agriculture. 32 (4): 257-261.

Sutardi, T. 1980. Landasan Ilmu Nutrisi I. Fakultas Peternakan. Institut Pertanian Bogor. Bogor.

Syahrir, N. Asmuddin., M. Zain., I. Rohmiyatul., A. Anie. 2012. Optimalisasi Biofermasi Rumen guna Meningkatkan Nilai Guna Jerami Padi sebagai Pakan Sapi Potong dengan Penambahan Biomassa Murbei dan Urea Mineral Molases Liquid (UMML) Universitas Hasanuddin Makasar, Makassar.

Syananta, F. P. 2009. Uji sifat fisik wafer limbah sayuran pasar dan palatabilitasnya pada ternak domba.
Fakultas Peternakan. Institut Pertanian Bogor. Bogor. (Skripsi)

Tillman, A. D., H. Hartadi, S. Reksohadiprodjo, $\mathrm{S}$. Prawirokusumo dan S. Lebdosoekojo. 1998. Ilmu Makanan Ternak Dasar. Cetakan ke lima. Gadjah Mada University Press, Yogyakarta.

Umiyasih, U. dan E. Wina. 2008. Pengolahan dan nilai nutrisi tanaman jagung sebagai pakan ternak ruminansia. Wartazoa. 18(3) : 127-136.

Utomo. R. 2015. Konservasi Hijauan Pakan dan Peningkatan Kualitas Bahan Pakan Berserat Tinggi. Gadjah Mada University Press. Bulaksumur, Yogyakarta.

Wayan, I. A. K., Y. Widodo dan Liman. 2015. Potensi Pakan Hasil Limbah Jagung (Zea mays L) di Desa Braja Harjosari Kecamatan Braja Selebah Kabupaten Lampung Timur. J. Ilmu Peternakan Terpadu 3(3) : 170-174.

Widiyanto. 2009. Utilitas pucuk tebu terolah dengan teknologi amofer sebagai pakan sapi Peranakan Ongole. Bul. Sintesa. 14(2) : 5-9. 